\title{
PENGARUH KETRAMPILAN PROSES SAINS TERINTEGRASI KARAKTER TERHADAP HASIL BELAJAR FISIKA
}

\author{
Imas Ratna Ermawati ${ }^{1}$ \\ Agnesia Bergita Anomeisa ${ }^{2}$ \\ Hendrik Seputra ${ }^{3}$ \\ Program Studi Pendidikan Fisika, FKIP UHAMKA ${ }^{1,3}$ \\ Program Studi Pendidikan Fisika, IKIP Muhammadiyah Maumere ${ }^{2}$ \\ Email: $\underline{\text { imas_re@uhamka.ac.id }}$
}

\begin{abstract}
This research was conducted to find out whether the test of science process skill integrated character to influence on high school physics learning result. The research was conducted at SMAN 1 Maumere in class XI MIA 1 as experiment class and XI MIA 2 as control class with material that is optical equipments in the even semester of academic year 2017/2018. The research method used is experiment with Quasi Experimental Quasi Experimental Experimental design that used is The Noneequivalent Pretest-Posttest Control Group Design „, while the research subject taking technique is Simple Random Sampling. Research subjects used amounted to 33 students both from the experimental class and control class. Before the research instrument is used first tested the validity and reliability test. In the validity test using Product Moment Pearson correlation, there are 24 tested questions and obtained the result of 18 valid questions and 6 drop problems. In reliability test by using Cronbach Alpha formula in get result rhitung $=0,870>0,329$; so the instrument is said to reliab with high interpretation. The next stage conducted data retrieval using instruments that have been valid and reliable then tested the prerequisite analysis in the form of normality test and homogeneity test. In the normality test using chi square obtained results; with a significant level of $\alpha=0.05$ and a sample size of 33 students in the experimental class and in the control class which means that the experimental and control classes are normally distributed. On the homogeneity test using $F$ test obtained the results,; with a significant level $\alpha=0.05$ and the number of samples of 33 students then the class of research is a homogeneous class. In the last stage, hypothesis testing with $t$-test and obtained the result,; with significant level $\alpha=$ 0.05 and the number of samples as many as 33 students, the skills of integrated science processes developed characters that influence the results of physics learning.
\end{abstract}

Keywords: Science Proces Skills, Character, Result of Physics Study 


\section{PENDAHULUAN}

Pendidikan adalah upaya manusia secara sadar yang tujuannya bersifat ganda, yaitu mengembangkan kepribadian dan kemampuan manusia. Salah satu hal yang tak bisa terlepaskan dalam bidang pendidikan adalah hasil belajar. Hasil belajar yang diperoleh dalam pembelajaran fisika dapat berbeda antara satu siswa dengan siswa yang lainnya. Penilaian merupakan salah satu faktor eksternal yang sangat mempengaruhi hasil belajar peserta didik. Salah satu prinsip penilaian adalah menyeluruh, dan berkesinambungan, dengan demikian guru harus menggunakan berbagai teknik penilaian yang sesuai dan mencakup semua aspek kompetensi untuk memantau perkembangan kemampuan peserta didik. Aspek kompetensi yang dimaksud adalah aspek kognitif (pengetahuan), aspek psikomotor (keterampilan), dan aspek afektif (sikap). Tujuan pembelajaran sains (fisika termasuk didalamnya) adalah untuk meningkatkan keterampilan siswa sehingga siswa bukan hanya sekedar menghafal, melainkan juga mampu dan terampil dalam bidang psikomotorik. Penyampaian pelajaran fisika yang masih bersifat konvensional, kurang menarik dan membosankan dapat menimbulkan ketidak tertarikan siswa terhadap pelajaran. Begitu juga sebaliknya, apabila pelajaran fisika disampaikan secara menarik dapat mendorong siswa untuk lebih giat dan meningkatkan pemahaman konsep terhadap pelajaran.

Pembelajaran fisika disekolah umumnya guru masih menjadi pusat dalam proses pembelajaran. Hal ini dapat terlihat dari hasil belajar fisika siswa yang masih rendah. Mulai dari mencari, mengumpulkan, memecahkan, dan menyampaikan informasi yang ditujukan, agar siswa memperoleh pengetahuan. Sehingga siswa kurang diberikan kesempatan untuk mengolah, mengontruksi, dan menentukan konsep sendiri dalam menggunakan pengetahuan yang sudah dimiliki siswa. Pemahaman konsep siswa kurang pada materi fisika karena pada proses belajar siswa hanya mengerjakan soal tanpa tau pemahaman dari apa yang dijelaskan oleh guru. Rendahnya kemampuan fisika siswa dapat dilihat 
dari tingkat pengetahuan dan dalam proses terjadi serangkaian pemahamannya terhadap materi aktivitas yang dilakukan oleh individu pelajaran. Salah satu cara untuk tersebut, maka hal itulah yang mengetahuinya adalah dengan menjadi nilai terbaik. Belajar dan memberikan tes atau soal tentang pembelajaran tidak bisa dipisahkan, materi tersebut kepada siswa.

Belajar adalah perubahan disposisi atau kemampuan yang dicapai seseorang melalui aktivitas. Perubahan disposisi tersebut bukan diperoleh langsung dari proses pertumbuhan seseorang secara alamiah (Suprijono, 2011). Belajar menurut peneliti adalah proses yang berlangsung seumur hidup. Dimana proses tersebut berisi serangkaian aktivitas. Aktivitas tersebut terdiri dari tingkah laku, pengetahuan, maupun psikomotorik. Harus ada pengulangan dari proses tersebut sehingga didapatkan perubahan tingkah laku, pengetahuan maupun psikomotorik yang lebih baik dari serangkaian proses tersebut. Perubahan seseorang dari segi perilaku, pengetahuan, dan keterampilan berdasarkan pengalaman individu tersbut, karena adanya motivasi. Selain itu belajar juga lebih cenderung menekankan pada proses bukan hasil, karena artinya guru mempunyai andil dalam proses perubahan tersebut, selain guru teman, keluarga maupun masyarakat juga berperan dalam proses perubahan tersebut.

Hasil belajar adalah pola-pola perbuatan, nilai-nilai, pengertianpengertian, sikap-sikap, apresiasi dan keterampilan (Suprijono, 2011). Hasil belajar merupakan kemampuan seseorang untuk mencapai ranah kognitif, afektif, dan psikomotorik. Pembelajaran sebagai hasil dari perubahan tingkah laku yang di alami oleh seseorang dimana perubahan tersebut adalah hasil dari pengalaman aktivitas belajar yang telah dilalui secara berulang-ulang. Fisika bukanlah sekedar kumpulan fakta dan prinsip.

Fisika adalah proses yang membawa kita pada prinsip-prinsip umum yang mendeskripsikan bagaimana perilaku dunia fisika (Sears \& Zemansky, 2001). Dapat disimpulkan bahwa fisika merupakan 
sebuah ilmu pengetahuan yang menjelaskan bagaimana sebuah prinsip umum dideskripsikan sebagai perilaku dunia fisika. Fisika juga bukan sekedar kumpulan fakta dan prinsip. fisika merupakan ilmu eksperimental yang mempelajari fenomena -fenomena alam sperti gerak, kalor, bunyi, cahaya dan magnet beserta interaksinya baik itu antar partikel dan yang lainnya yang sesuai dengan hukum-hukum fisika yang berlaku. Oleh karena itu, dapat disimpulkan bahwa hasil belajar fisika kemampuan seseorang dalam memahami materi fisika untuk mencapai ranah kognitif, afektif, dan psikomotorik pada pembelajaran fisika. Pembelajaran sebagai hasil dari perubahan tingkah laku yang dialami oleh seseorang dimana perubahan tersebut adalah hasil dari pengalaman aktivitas belajar fisika yang telah dilalui secara berulangulang.

Karakter juga diartikan hasil dari suatu proses. Menurut Kemendiknas (2010a: 3), karakter adalah watak, tabiat, akhlak, atau kepribadian seseorang yang terbentuk dari hasil internalisasi berbagai kebajikan (virtues) yang diyakini dan digunakan sebagai landasan untuk cara pandang, berpikir, bersikap, dan bertindak (Kementerian Pendidikan Nasional, 2010). Karakter merupakan perilaku terhadap semua komponen kehidupan yang berhubungan. Karakter adalah sifat pribadi yang relatif stabil pada diri individu yang menjadi landasan bagi penampilan perilaku dalam standar nilai dan norma yang tinggi. bersifat pribadi artinya ciri-ciri yang ada didalam individu seseorang yang diwujudkan dalam tingkah laku relatif stabil adalah suatu kondisi yang apabila telah terbentuk akan tidak mudh diuabh. (Budimansyah, 2012:2). Ada enam pilar penting karakter manusia yang dapat digunakan untuk mengukur dan menilai watak/ perilakunya, yaitu penghormatan, tanggung jawab, kesadaran berwarganegara, keadilan, kepedulian dan kemauan berbagi,serta kepercayaan. Berdasarkan kerangka acuan Pendidikan karakter (Kemendiknas, 2010a: 9-10) ada 18 karakter yang diintegrasikan ke dalam pendidikan di sekolah. Nilai-nilai tersebut antara lain religius, jujur, toleransi,disiplin, kerja keras, kreatif, 
mandiri, demokratis, rasa ingin tahu, semangat kebangsaan, cinta tanah air, menghargai prestasi, komunikatif, cinta damai, senang membaca, peduli sosial, peduli lingkungan, dan tanggungjawab. Pada integrasi karakter pada pokok bahasan optik untuk meningkatkan enam nilai karakter, yaitu: disiplin, jujur, rasa ingin tahu, kreatif, kerja keras, dan tanggung jawab.

KPS merupakan adaptasi dari keterampilan yang digunakan oleh para ilmuwan untuk menyusun suatu konsep, menyelidiki suatu masalah dan membuat kesimpulan atas masalah yang ditelitinya (Karsli dkk, 2010: 778). Keterampilan Proses Sains menurut Chiapetta (1997) dibagi menjadi dua, yaitu keterampilan proses sains dasar dan terintegrasi. Dimyati dan Moedjiono (2009), ada berbagai keterampilan proses, keterampilan-keteramilan tersebut terdiri dari keterampilan dasar proses sains, dimulai dari mengobservasi, mengklasifikasi, memprediksi, mengukur, menyimpulkan dan mengkomunikasikan, dan keterampilan terpadu proses sains dari identifikasi variabel sampai dengan yang paling kompleks, yaitu eksperimen. Sedangkan menutut Chiapetta (1997), keterampilan proses sains dasar menurut mengacu pada keterampilan mengamati, berkomunikasi, mengklasifikasikan, mengukur secara metrik, menyimpulkan, dan memprediksi. Keterampilan terintegrasi terdiri atas mendefinisikan, merumuskan model, mengendalikan variabel, menafsirkan data, berhipotesis, dan bereksperimen.

Berdasarkan pendapat ahli dapat disimpulkan bahwa keterampilan proses sains merupakan sebuah kecakapan yang dapat dihasilkan dari kemampuan diri sendiri serta sekelilingnya yang telah ada dalam diri yang berfungsi sebagai awal suatu perubahan untuk kemampuan yang lebih pesat yang berasal dari kemampuan dasar. Keterampilan proses yang harus dimiliki siswa berdasarkan pendapat ahli yaitu dibagi menjadi 11 aspek yaitu: pengamatan, mengukur, berhipotesis, merencanakan, mencoba, menafsirkan data, menggunakan data, percobaan, menyimpulkan, menerapkan, Pembahasan, Mengkomunikasikan 


\section{METODE}

Penelitian ini dilaksanakan di Sekolah Menengah Atas Negeri 1 Maumere NTT Metode penelitian yang digunakan adalah Quasi Experimental Design. Desain penelitian yang digunakan yaitu Quasi Experimental. Dengan demikian desain dalam penelitian ini terdapat satu kelompok yang tidak diberikan perlakuan disebut kelompok kontrol dan satu kelompok yang diberikan perlakuan disebut kelompok eksperimen.

Pemahaman Pada penelitian kali ini, keterampilan proses sains siswa dapat di ukur dengan lembar observasi pada saat kegiatan praktikum. Lembar observasi untuk mengukur keterampilan proses sains siswa memiliki 11 aspek keterampilan proses sains. Untuk menilai kemampuan pemahaman konsep dapat dilakukan dengan menggunakan tes uraian bebas dengan 7 indikator pemahaman konsep.

Dalam kelompok kontrol dan kelompok eksperimen, sebelum dilakukan penelitian diberikan pretest untuk mengukur kemampuan awal siswa. Pretest yang diberikan pada kelompok kontrol sama dengan pretest yang diberikan pada kelompok eksperimen yaitu keterampilan proses sains.

Adapun sampel yang digunakan dalam penelitian ini adalah siswa kelas XI MIA 2 sebagai kelas kontrol dan XI MIA 1 sebagai kelas eksperimen.

\section{HASIL DAN PEMBAHASAN}

Pada tabel 1 diperoleh data dari penelitian ini berupa hasil belajar fisika yang terintegrasi karakter. berdasarkan data yang diperoleh, perkembangan karakter yang didapat melalui dari angket karakter dan observasi tidak jauh beda. Perbedaan nilai angket dan observasi terjadi karena karakter yang ada pada diri siswa tidak dapat diamati secara optimal. Hasil tersebut lebih lanjut dapat dilihat pada gambar 1 . Ada 2 faktor yang mempengaruhi perkembangan karakter terdiri dari faktor internal dan faktor eksternal. Menurut Daryanto \& Darmiatun (2013) faktor internal misalnya instink biologis, kebutuhan psikologis, dan kebutuhan pemikiran 
serta faktor eksternal misalnya pembelajaran tetapi juga ditentukan lingkungan keluarga, sosial dan oleh lingkungan sosial dalam pendidikan. Sehingga keberhasilan memberikan situasi yang kondusif pendidikan karakter tidak ditentukan untuk perkembangan karakter. besarnya peran pendidik dalam

Tabel 1. Persentase Tiap-Tiap Perkembangan Karakter

\begin{tabular}{|c|c|c|c|c|c|c|}
\hline \multirow[t]{2}{*}{ Karakter } & \multicolumn{2}{|c|}{$\begin{array}{c}\text { Perkembangan } \\
(\%)\end{array}$} & \multicolumn{2}{|c|}{ Kriteria } & \multirow{2}{*}{$\begin{array}{c}\text { Hasil } \\
\text { Uji } \\
\text { Gain }\end{array}$} & \multirow[t]{2}{*}{$\begin{array}{c}\text { Kriteria } \\
\text { Gain }\end{array}$} \\
\hline & Sebelum & Sesudah & Sebelum & Sesudah & & \\
\hline Jujur & 68,27 & 80,94 & $\begin{array}{c}\text { Mulai } \\
\text { Berkembang }\end{array}$ & Membudaya & 0,433 & Sedang \\
\hline Disiplin & 63,66 & 78,34 & $\begin{array}{c}\text { Mulai } \\
\text { Berkembang }\end{array}$ & $\begin{array}{c}\text { Mulai } \\
\text { Berkembang }\end{array}$ & 0,430 & Sedang \\
\hline $\begin{array}{l}\text { Rasa } \\
\text { Ingin } \\
\text { Tahu }\end{array}$ & 55,44 & 65,34 & $\begin{array}{c}\text { Mulai } \\
\text { Berkembang }\end{array}$ & Membudaya & 0,244 & Rendah \\
\hline Kreatif & 66,78 & 80,73 & $\begin{array}{c}\text { Mulai } \\
\text { Berkembang }\end{array}$ & Membudaya & 0,453 & Sedang \\
\hline $\begin{array}{l}\text { Kerja } \\
\text { Keras }\end{array}$ & 64,23 & 83,00 & $\begin{array}{c}\text { Mulai } \\
\text { Terlihat }\end{array}$ & $\begin{array}{c}\text { Mulai } \\
\text { Berkembang }\end{array}$ & 0,5 & Sedang \\
\hline $\begin{array}{c}\text { Tanggung } \\
\text { Jawab }\end{array}$ & 71,00 & 83,10 & $\begin{array}{c}\text { Mulai } \\
\text { Berkembang }\end{array}$ & Membudaya & 0,43 & Sedang \\
\hline
\end{tabular}

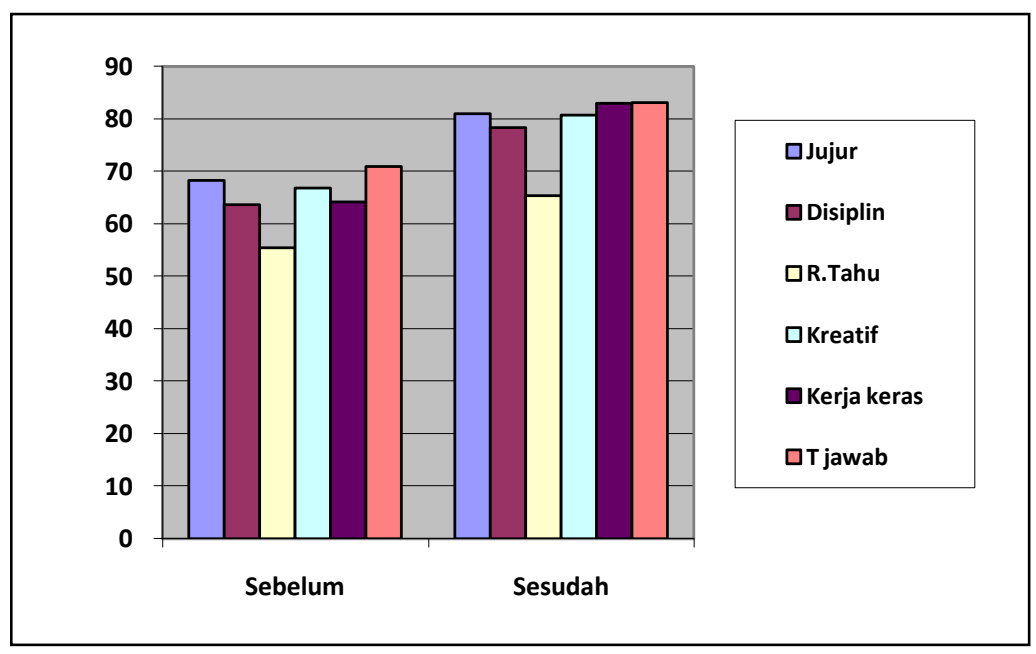

Gambar 1. Grafik Perkembangan Karakter

Uji Normalitas yang digunakan untuk signifikan $\alpha=0,05$. Berdasarkan kelas eksperimen dan kelas kontrol Tabel 2 diketahui nilai yaitu uji chi kuadrat pada taraf $\chi^{2}$ hitung $=6,6245$ dan 
$\chi^{2}$ tabel $=7,81$ dengan taraf $\chi^{2}$ hitung $<\chi^{2}$ tabel maka terima signifikansinya $\alpha=0,05$ dan jumlah $\mathrm{H}_{0}$, artinya berarti berdistribusi siswa (n) sebanyak 33 siswa. normal.

Sehingga dapat disimpulkan

Tabel 2. Hasil Uji Normalitas

\begin{tabular}{ccccc}
\hline $\mathrm{n}$ & $\mathrm{db}$ & $\alpha$ & $\chi^{2}$ hitung & $\chi^{2}$ tabel \\
\hline 33 & 3 & $\mathbf{0 , 0 5}$ & $\mathbf{6 , 6 2 4 5}$ & $\mathbf{7 , 8 1}$ \\
\hline
\end{tabular}

Tabel 3. Hasil Uji Homogenitas

\begin{tabular}{ccccc}
\hline $\mathrm{n}$ & $\mathrm{dk}$ & $\boldsymbol{\alpha}$ & $F_{\text {hitung }}$ & $F_{\text {tabel }}$ \\
\hline$n_{x}=33$ & $d b_{x}=32$ & 0,05 & 1,76 & 1,808 \\
\hline
\end{tabular}

Berdasarkan Tabel 3 hasil dengan uji t. Dengan kriteria perhitungan uji homogenitas dengan pengujian hipotesis jika maka derajat kebebasan pembilang 33 dan terdapat perbandingan hasil belajar penyebut 33 maka didapatkan fisika dengan menggunakan $F_{\text {hitung }}=1,76$ dan nilai $F_{\text {tabel }}=$ keterampilan proses sains. jika 1,808 dengan taraf signifikansinya keterampilan proses sains Sehingga $\alpha=0,05$. Sehingga $\quad F_{\text {hitung }}>\quad$ dari pengujian hipotesis menggunakan $F_{\text {tabel }}$ sehingga dapat disimpulkan, $\mathrm{H}_{\mathrm{o}}$ diterima. Sebelum dilakukan uji hipotesis, terlebih dahulu melakukan pengujian prasyarat analisis, yang terdiri dari pengujian normalitas dan homogenitas maka dapat disimpulkan bahwa kelas berdistribusi normal dan homogen. Selanjutnya yaitu uji $\mathrm{t}$ didapatkan data yang diperoleh pada Tabel 4.

Dari Tabel 4 nilai yang didapatkan dari tabel $\mathrm{t}$ dengan taraf signifikan dan derajat kebebasan $(\mathrm{dk})=64$ didapat $t_{\text {tabel }}=1,998$. Karena, $t_{\text {hitung }}=3,250>t_{\text {tabel }}=$ melakukan pengujian hipotesis

Tabel 4. Hasil Uji Hipotesis

\begin{tabular}{cccc}
\hline $\mathbf{n}$ & $\mathbf{d b}=\mathbf{d k}$ & $t_{\text {hitung }}$ & $t_{\text {tabel }}$ \\
\hline$n_{x}=33$ & $\mathrm{Db}=64$ & 3,250 & 1,998 \\
\hline
\end{tabular}


Dengan demikian dapat diartikan bahwa keterampilan proses sains yang dikembangkan berpengaruh terhadap kelas Eksperimen.

\section{PENUTUP}

\section{Kesimpulan}

Berdasarkan hasil penelitian dan pembahasan dapat disusun simpulan sebagai berikut:

Fisika pokok bahasan optik yang dikembangkan adalah diintegrasikan karakter dengan berbantuan Microsoft Powerpoint 2013 yang dilengkapi video dan animasi, dapat merespon suatu jawaban dari pertanyaan berupa benar atau salah apabila siswa menekan tombol yang ada, berbentuk soft file yang terintegrasi karakter jujur, disiplin, rasa ingin tahu, kreatif, kerja keras dan tanggung jawab melalui instruksi atau petunjuk sebelum pembelajaran di dalam kelas serta disisipkan kalimat motivasi dari para pakar di setiap sub materi.

Keterampilan proses sains fisika pokok bahasan optik terintegrasi karakter dapat meningkatkan hasil belajar aspek kognitif siswa SMAN 1 Maumere NTT yang tinggi dan fisika pokok bahasan optik terintegrasi karakter dapat mengembangkan karakter siswa SMAN 1 Maumere NTT. Karakter yang dintegrasikan jujur, disiplin, rasa ingin tahu, kreatif, kerja keras dan tanggungjawab dengan peningkatan sedang. Respon siswa berada pada kriteria baik yang terdiri dari aspek perhatian, keterkaitan, kepercayaan diri, dan kepuasan. Selain itu, berdasarkan hasil uji hipotesis dapat diketahui bahwa keterampilan proses sains terintegrasi karakter dikembangkan berpengaruh terhadap kelas Eksperimen.

\section{DAFTAR PUSTAKA}

Budimanysah, Dasim. (2012). Upaya membina karakter bangsa melalui buku nonteks pelajaran. Bogor: Pusat Kurikulum dan Perbukuan Badan Penelitian dan Pengembangan Kementerian Pendidikan dan Kebudayaan.

Chiappetta, E.L. (1997). Inquirybased science. The Science Teacher; Oct 1997; 64, 7; ProQuest Education Journals, 22-26.

Daryanto \& Darmiatun, S. (2013). Implementasi Pendidikan Karakter di Sekolah. Yogyakarta: Gava Media.

Direktorat Ketenagaan Direktorat Jenderal Pendidikan Tinggi Kementerian Pendidikan Nasional . (2010). Kerangka 
I, R, Ermawati., A, B, Anomeisa., H, Seputra. - Pengaruh Keterampilan ...

Acuan Pendidikan Karakter

Tahun Anggaran 2010.

Karsli, F., Yaman, F., \& Ayas, A. (2010). Prospective chemistry teachers' competency of evaluation of chemical experiments in terms of science process skills. Procedia-Social and Behavioral Sciences, 2(2), 778-781.

Samani, M. \& Hariyanto. (2011). . Konsep dan Model Pendidikan Karakter. Bandung: PT Resmada Rosdakarya.

Sears, \& Zemansky. (2001). Fisika Universitas I. Bandung : Erlangga.

Suprijono, A. (2012). Cooperative Learning Teori dan Aplikasi Paikem. Yogyakarta: Pustaka Pelajar. 